\title{
A review of state statutes regulating financial derivatives in the USA
}

Received: 20th September, 2003

\section{Greg Kaza}

served three terms (1993-98) in the Michigan House of Representatives where he wrote nine laws, including Michigan Public Act 15.422. He taught economics at Walsh College and Northwood University in Troy, Michigan, and is Executive Director of the Arkansas Policy Foundation, a non-partisan economic research organisation based in Little Rock.

\begin{abstract}
This paper presents a review of state statutes in the USA that define or regulate financial derivatives. Forty-three states have legal definitions or regulate private enterprises that use derivatives. The most frequent reference is in state Uniform Principal and Income Acts. There is little transparency of government units, including public retirement systems. Three states (Kansas, Missouri and Wisconsin) severely restrict the use of derivatives by public funds. Michigan enacted a statute requiring transparency for government units. There is no statutory reference to financial derivatives in seven states.
\end{abstract}

Keywords: financial derivatives; government transparency; Uniform Principal and Income Act

\section{Summary}

The California Public Employees Retirement System (CalPERS), following the 1994 bankruptcy of Orange County, adopted a transparency policy, ie a statement of financial derivatives investment policy. A review of state statutes in the USA referencing derivatives shows regulation of private corporations but little transparency of government units, including public retirement systems. Forty-three states have legal definitions of derivatives or

Tel: +1501537 0825; e-mail: gregkaza@yahoo.com regulate private enterprises that use them. The most common reference to derivatives is found in state Uniform Principal and Income Acts. Three states (Kansas, Missouri and Wisconsin) severely restrict the use of derivatives by public funds. Michigan enacted a statute requiring transparency for government units. There is no statutory reference to derivatives in seven states (Delaware, Massachusetts, Mississippi, New Hampshire, Nevada, Rhode Island and South Dakota).

\section{California}

Orange County, California, is perhaps the best-known example of a government unit in the USA losing public funds through the misuse of financial derivatives. In 1994, Orange County announced a $\$ 1.6 \mathrm{bn}$ loss, the largest ever recorded by a local government investment pool. According to 1998 testimony $^{1}$ before the Senate Committee on Agriculture, Nutrition, and Forestry, approximately 187 
municipalities and government units deposited tax revenues and other public moneys in several pools, including a commingled pooled fund (the 'County Pools'). The County Pools were managed by the Orange County treasurer and totalled approximately $\$ 7.6 \mathrm{bn}$. The treasurer employed a strategy of leverage using reverse repurchase agreements based on the assumption that interest rates would remain low. The treasurer's aggressive use of leverage compounded losses in the investment pools. The estimated $\$ 7.6$ bn in deposits was leveraged to more than $\$ 20 \mathrm{bn}$. The strategy worked until the Federal Reserve Open Market Committee (FOMC) raised the Intended Fed Funds rate six times, starting in February 1994. Orange County declared bankruptcy in December 1994.

Following the bankruptcy, CalPERS adopted a transparency policy, ie a statement of financial derivatives investment policy. The purpose of CalPERS' policy ('the Policy') ${ }^{2}$ is to establish the 'permitted circumstances, parameters, and requirements for the use of Investment Derivatives by External Money Managers ("the Program").' The Policy is meant to ensure 'that investors, managers, consultants, or other participants selected' by CalPERS 'take prudent and careful action while managing the Program'. It encourages risk control, ignored by Orange County. The Policy also prohibits speculation, which involves entering into a transaction where there is no underlying related asset; derivative exposure is the transaction's purpose. The Orange County bankruptcy involved speculation.

The Policy defines derivative investment 'as an instrument that derives its value, usefulness, and marketability from an underlying instrument which represents direct ownership of an asset or a direct obligation of an issuer (ie a 'spot' or cash market instrument)'. CalPERS, which defines itself as 'a significant global institutional investor', is positioned for 'taking advantage of derivative instruments to ensure the overall investment performance objective is achieved as specified'. Four basic strategies, the Policy states, can be achieved through the use of derivatives. Two strategies (substitution and risk control) are permitted under the Policy; two others (arbitrage and speculation) are prohibited.

\section{Substitution}

'When the characteristics of the derivative sufficiently parallel those of the cash market instrument, the derivative may be substituted on a short-term basis for the cash market instrument, or on a longer-term basis to avoid withholding taxes. This strategy is particularly useful when investing cash flow or liquidating investments, as the derivative can be used to manage more precisely the market entry and exit points.'

\section{Risk control}

'When characteristics of the derivative instrument sufficiently parallel those of the cash market instrument, an opposite position in the derivative can be taken from the cash market instrument to alter the exposure to or the risk (volatility) of the cash instrument. This strategy is useful to manage risk without having to sell the cash instrument.' Risk control is sometimes referred to as 'hedging'.

\section{Arbitrage}

'When the characteristics of a derivative are more attractive than either the cash market instrument or another related derivative, the first derivative is 
purchased, or the cash market instrument is swapped to garner the short-term return potential from the derivative instrument alone. This strategy is particularly useful for capturing mis-pricing in the derivative instrument relative to either the cash market instrument or another derivative.'

\section{Speculation}

'When the characteristics of the derivative are the sole reason for its purchase or sale where an underlying naked cash position is taken in the portfolio. This strategy also implies the leveraging of the portfolio, which may create an obligation of value in excess of the value of that portfolio.'

The Policy (General Requirements And Restrictions) requires each external manager to 'prepare, maintain, and periodically review a written derivatives policy' that includes the following:

— 'Specifies the philosophy and prescribed use of derivatives for client accounts.'

— 'Establishes limits to derivatives exposure within a client account expressed in terms of percentage of notional amount of derivatives exposure as a percent of market value.'

— 'Establishes a standard of care' including 'separation of responsibilities; senior management supervision; the required expertise of those permitted to engage in the use of derivatives; and the authority of those permitted to use derivatives'.

- 'Describes the compensation of traders, portfolio managers, and other individuals involved in the use of derivatives to avoid inappropriate, fraudulent, or non-compliant behavior; and specifies the periodic review of the written derivatives policy.'
Managers are required to mark-to-market derivative positions daily, use a daily pricing source for valuing derivative positions and reconcile daily cash and margin positions with CalPERS' master custodian bank.

The Policy (Counter-Party Requirements) requires each manager to 'prepare, maintain, and periodically review a counter-party credit policy for non-exchange-traded derivatives' that meets 12 standards. These standards: include outlining acceptable credit standards a counter-party must meet and how it will be evaluated against those standards; specify a list of approved counter-parties with credit exposure limits; and provide for the independent audit of credit policy procedures to ensure compliance. The separation 'of trading (dealing) activity responsibilities from credit approval and review responsibilities' is required as is 'a separate risk management function within the firm, or an appropriate set of checks and balances to ensure proper risk management'. The Policy defines 'counter-party creditworthiness' as equaling 'an "investment grade" of "A3" as defined by Moody's Investor Service or "A-" by Standard \& Poor's'. The use of counter-parties holding a split rating with one of the ratings below A3/A- is prohibited as is the use of unrated counter-parties. Non-exchange traded derivatives or individual counter-party exposure, under the Policy, 'are limited to 33 percent of the notional amount of the derivative exposure of the portfolio being managed for the System. An exception is allowed if total derivative exposure in the portfolio is less than $\$ 100$ million'.

The Policy (Permitted And Restricted Instruments) defines 'classes of derivatives'.

Regarding futures contracts, stock index futures, bond futures and currency 
futures which are Commodities and Futures Trading Commission (CFTC)-approved are permitted when the manager has permission to invest in the underlying or deliverable cash market instrument.

The use of options and currency forward contracts are permitted under the same criteria or when the purpose is 'to overlay a designated portfolio of deliverable cash market instruments'. Swaps 'which provide for the receipt of the rate of return of the permitted cash market instrument' are also allowed.

Options on futures are prohibited. Structured notes (such as, but not limited to, inverse floaters) are not considered derivatives for the purposes of the Policy, and are prohibited, 'unless expressly permitted by the manager's investment guidelines included in its contract with the System'. The purchase of warrants is prohibited except when they are 'attached to securities authorized for investment'.

The Policy (Criteria for New Derivatives) provides the "use of any new derivative shall only occur upon written authorization of the System's Chief Investment Officer or his/her authorized designee ... Because most derivative instruments are traded under unregulated circumstances, a "common law" practice shall prevail. Before use of a new derivative, at least three market makers shall review and support it'. They 'shall have adequate capitalization, exemplary reputations in the marketplace' and counter-party creditworthiness as defined elsewhere in the Policy.

The Policy also requires managers to prepare a monthly report that explains 'the derivatives and the counter-parties used and the market value, cost-value, gain or loss, notional exposure, and amount of exposure; a description of the strategy and expected outcome of the derivative use; and the quantified impact to the portfolio'.
The CalPERS Policy is the most comprehensive derivative investment policy created by a government unit in the 50 states. The Policy is not codified, yet its definition of terms is more comprehensive than any statute regulating derivatives.

\section{The Uniform Principal and Income Act}

The most frequent references to derivatives in state statutes in the USA are found in state Uniform Principal and Income Acts.

In 1999, the California Assembly enacted a model 'Uniform Principal and Income Act' that includes the following broad legal description of 'derivative':
"In this section, "derivative" means a contract or financial instrument or a combination of contracts and financial instruments that gives a trust the right or obligation to participate in some or all changes in the price of a tangible of intangible asset or group of assets, or changes in a rate, or index of prices or rates, or other market indicator for an asset or a group of assets.'

The California Act regulates trustees' use of financial derivatives. It is an example of a state statute regulating private corporations. The California Assembly, in passing the Act, ${ }^{3}$ followed the example of other state legislatures.

The definition of 'derivative' contained in the California Act is derived from s. 414(a) of the Uniform Principal and Income Act (termed hereafter as 'the Act.') Legal references to derivatives appear more frequently in this Act than in any other statute.

In 1997, the National Conference of Commissioners on Uniform State Laws drafted revisions ${ }^{4}$ to the 1931 Act and the 1962 Revised Act. The purpose of the 1997 Second Revised Act was twofold: 


\section{Revision}

The old acts needed revision 'to support the now widespread use of the revocable living trust as a will substitute, to change the rules in those Acts that experience has shown need to be changed, and to establish new rules to cover situations not provided for in the old Acts, including rules that apply to financial instruments invented since 1962'. These new instruments include 'derivatives' which are defined in s. 414(a).

\section{Uniform Prudent Investor Act}

'The other purpose is to provide a means for implementing the transition to an investment regime based on principles embodied in the Uniform Prudent Investor Act, especially the principle of investing for total return rather than a certain level of "income" as traditionally perceived in terms of interest, dividends, and rents.'

The Act's treatment of derivatives is less ambitious than the CalPERS policy. The Act's Official Comment explains: 'The Board considered defining a derivative financial instrument by merely referencing those commonly understood instruments' and defining them as 'a futures, forward, swap or option contract, or other financial instrument with similar characteristics'. The Board noted 'the continued development of financial markets and innovative financial instruments could ultimately render a definition based on examples inadequate and obsolete'. The Board, therefore, 'decided to base the definition of a derivative financial instrument on a description of the common characteristics of those instruments in order to accommodate the accounting for newly developed derivatives'.

The Act's Official Comment observes: " "Derivative" is a difficult term to define because new derivatives are invented daily as dealers tailor their terms to achieve specific financial objectives for particular clients. Since derivatives are typically contract-based, a derivative can probably be devised for almost any set of objectives if another party can be found who is willing to assume the obligations required to meet those objectives. The most comprehensive definition of derivative is in the Exposure Draft of a Proposed Statement of Financial Accounting Standards titled "Accounting for Derivative and Similar Financial Instruments and for Hedging Activities", which was released by the Financial Accounting Standards Board (FASB) in June 1996 (No. 162-B).

The definition in s. 414(a) is derived in part from the FASB definition. The purpose of the definition in subsection (a) is to implement the substantive rule in subsection (b) that provides for all receipts and disbursements to be allocated to principal to the extent the trustee elects not to account for transactions in derivatives under s. 403. As a result, it is much shorter than the FASB definition, which serves much more ambitious objectives.'

A review of state statutes shows legislatures in 31 states have passed a version of the Act regulating trustees and defining financial derivatives: Alabama (1975, 19-3A-101); Alaska (13.28.740); Arizona (14-7401-7431); Arkansas (28-70-414); California (Probate 1-6366); Colorado (15-1-401); Connecticut (45a-542v); Florida (738.607) Georgia (33-11-51); Hawaii (557A-101); Idaho (68-10-414); Iowa (1CA 637.101); Kansas (58-9-101); Maryland (15-501); Missouri (469.477); Montana (72-34-446); Nebraska (30-3140); New Jersey (3B:19B-22); New Mexico (46-3A-101); North Dakota (59-04.2-01); Ohio (340.76); Oklahoma (60-175.101); Oregon (Chapter 279); Pennsylvania (Pa. CSA 
20-8154); South Carolina (62-7-423);

Tennessee (35-6-101); Utah (22-3-1);

Vermont (8-3461); Virginia (1950,

55-277.1); West Virginia (44B-1-101); and Wyoming (2-3-824).

Three states have enacted Uniform Principal and Income Acts that do not contain any reference to derivatives:

Mississippi (91-17-1); Nevada

(164.140); and South Dakota

(55-13-1).

There is no statutory reference to derivatives in four other states (Delaware, Massachusetts, New Hampshire and Rhode Island ${ }^{5}$ ).

\section{State regulation of derivatives in insurance codes}

At least 13 states have enacted statutes defining and regulating the use of derivatives by the private sector. The most common way is to regulate insurance companies.

The purpose of Illinois' Act (the Illinois Insurance Code) is to protect the interests of insureds by promoting insurer solvency and financial strength. This will be accomplished through the application of investment standards that facilitate a reasonable balance of the following objectives:

1. To preserve principal;

2. To assure reasonable diversification as to type of instrument, insurer and credit quality; and

3. To allow insurers to allocate investments in a manner consistent with principles of prudent investment management to achieve an adequate return so that obligations to insureds are adequately met and financial strength is sufficient to cover reasonably foreseeable contingencies'. (Illinois 215 ILCS 5/126.1)

Other states with similar statutes include:
Colorado (10-3-243); Indiana (27-1-12); Kentucky (304.7-419); Maine (24-A 1151-A); Minnesota (60L): Montana (33-12-101); Nebraska (44-5149); New York (INS 1410); North Carolina (58-7-205(a)); Tennessee (56-3-302); Texas (INS 2.10-4); and Washington (48.13.285).

\section{State regulation of government units}

State regulation of government units that use derivatives is less extensive than the number of statutes regulating private corporations. Few states encourage transparency.

Florida (218.415) specifies that 'the unit of local government's officials responsible for making investment decisions or chief financial officer have developed sufficient understanding of the derivative products and have the expertise to manage them'. The statute also requires a written policy.

Louisiana (33.2955) requires government units to 'establish internal controls for any derivatives in use to ensure that the risks inherent in derivatives are adequately managed'.

Three states prohibit or restrict the use of derivatives by public funds: Kansas, Missouri and Winsconsin.

Kansas has two statutes: one regulating 'state moneys' (75-4209) and a second applicable to 'municipalities, investments' (10-131).

The statute on state moneys runs as follows:

\footnotetext{
'The director of investments shall not invest money in the pooled money investment portfolio in derivatives. As used in this subsection, "derivatives" means a financial contract whose value depends on the value of an underlying asset or index of asset values.'
} 
Table 1: Legislative position in the 50 states

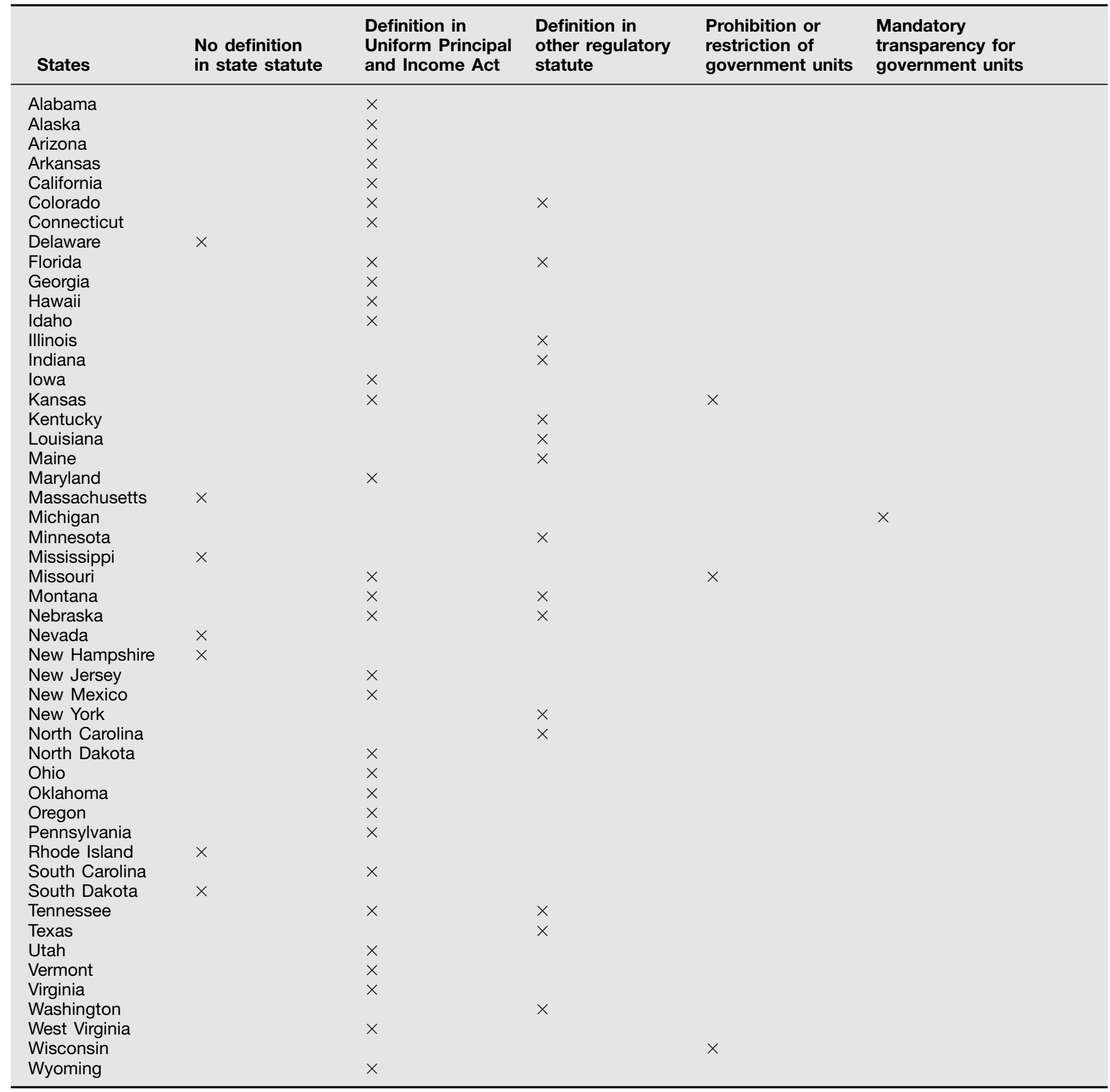

The definition was amended following a 1998 Kansas Attorney General's Opinion (1998-32) that authorised investment of state moneys in tri-party repurchase agreements.
The statute on municipal units runs as follows:

'General bond law. Investment of proceeds of bonds or temporary notes and certain funds authorised. No money 
authorised to be invested ... shall be invested in a derivative. For the purposes of this section, "derivative" means any investment instrument whose market price is derived from the fluctuating value of an underlying asset, index, currency, (or) futures contract, including futures, options and collateralized mortgage obligations.'

Missouri (30.950) requires, 'Every political subdivision of this state which is responsible for the management and investment of public funds and which has existing authority to invest such funds in a manner other than depository accounts at financial institutions in this state shall promulgate, formally adopt and comply with a written investment policy containing, but not limited to, the following components:

- A prohibition on the purchase of derivative securities, either directly through a repurchase agreement;

- A prohibition on the use of leveraging whether through a reverse repurchase agreement or otherwise; or prohibition on the use of public funds for speculation.

- A prohibition on the use of public funds for speculation.'

Two Great Lakes states, Wisconsin and Michigan, took different approaches to derivatives after the loss of public funds by government units.

The Wisconsin Investment Board lost more than $\$ 95 \mathrm{~m}$ through positions in leveraged derivative instruments linked to movements in the Mexican economy and the peso's value. ${ }^{1}$ Independence Townships, Michigan, lost $\$ 2 \mathrm{~m}$ on domestic swaps.

Wisconsin (25.183) regulates Public Domain and the Trust Funds, Trust Funds and Their Management. The Act reads, 'After May 7, 1996, the board may not purchase or acquire any derivative in the state investment fund except in accordance with rules promulgated by the board (State of Wisconsin Investment Board). Rules promulgated under this subsection may not permit the purchase or acquisition of derivatives in the state investment fund unless the purchase or acquisition is made for the purpose of reducing risk of price changes or of interest rate or currency exchange rate fluctuations with respect to investments held or to be held by the board.'

Michigan (15.422) created the 'Good Government Financial Report Disclosure Act', which requires derivatives to be reported in 'an audit report or other report for a local unit'. The Act also applies to state government, including pension funds. It requires reporting of 'the cost and fiscal year end market value of derivative instruments or products in the local unit's pension or nonpension investment portfolio at year end reported on an aggregate basis and itemized by issuer and type of derivative instrument or product .... Government units are required to disclose this information to the state treasurer or auditor general. The act creates a depository for the reports, and subjects their release to the public under the state Freedom of Information Act. It has been in effect since 1996.

\section{Conclusion}

The bankruptcy of Orange County, California occurred a decade ago. Yet attempts to create transparency for government units, including public retirement systems, are in their infancy at the state government level in the USA. The CalPERS Policy is the most comprehensive derivative investment policy applicable to a government unit. It could serve as a model for state legislators if they conclude government transparency should be a policy goal. 
The most common reference to derivatives in the interim is likely to remain in state Uniform Principal and Income Acts that regulate private corporations.

\section{References}

1 'Testimony Concerning OTC Derivatives in the U.S. Financial Markets,' Richard R. Lindsey, Director, Division of Market Regulation, US Securities \& Exchange Commission Before the Senate Committee on Agriculture, Nutrition, and Forestry, 16th December, 1998.

2 California Public Employees Retirement System
(1996) 'Statement Of Derivatives Investment Policy For External Money Managers', 5th December.

3 California Probate 1-6366, 'Uniform Principal \& Income Act'.

4 'Uniform Principal And Income Act (1997)', National Conference Of Commissioners On Uniform State Laws.

5 The Rhode Island Uniform Security Act (7-11-101) does not define 'derivatives' but includes the following description of 'security': 'a put, call, straddle, or option entered into on a national securities exchange relating to foreign currency; put, call, straddle or option on a security, certificate of deposit, or group or index of securities, including an interest in or based on the value of any of the proceeding.' 